\title{
PEMIKIRAN AHMAD SYAFII MAARIF TENTANG NEGARA DAN SYARIAT ISLAM DI INDONESIA
}

\author{
Ahmad Asroni \\ Religions and Tolerance Studies Forum Yogyakarta dan PPS UIN Sunan Kalijaga \\ Yogykarta. \\ E-mail: ahmad.asroni@gmail.com
}

\section{Abstract}

The discourse of Islamic state and the implementation of the sharia (Islamic law) has been an endless issue to be discussed. This issue is still debatable for various parties. In one sense, it is accepted and even supported. In other sense, it is blasphemed and criticized. In the reality of global politics, the efforts to establish Islamic state and the implementation of the sharia has been practiced by many Islamic countries including Indonesia. This paper tries to explore Abmad Syafii Maarif's thought concerning the discourse of Islamic state and the implementation of the sharia. Ahmad Syafii Maarif refuses the efforts to establish Islamic state and the implementation of the sharia by unconstitutional and undemocratic ways. He criticizes people promoting the discourse. Besides theological and historical reasons, he argues that the discourse will have no benefit. In his perspective, Islam is adequately positioned as an ethical foundation of nation.

كان تعبيرُ دولة الإسلام و تطبيقُ الشريعة الإسلامية مسألتَّن لا تنتهيًا للبحث.و

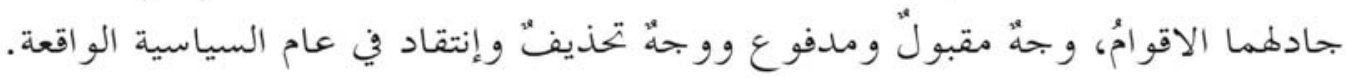

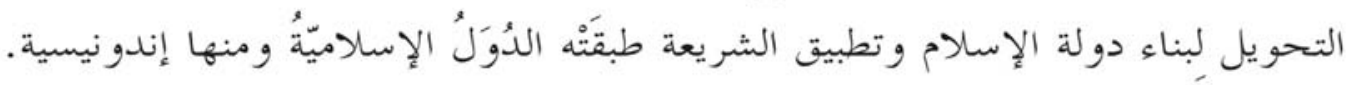

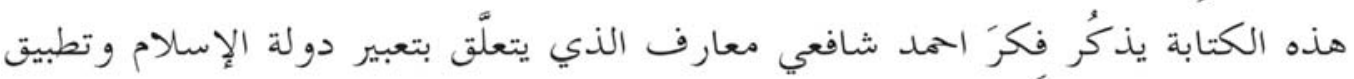

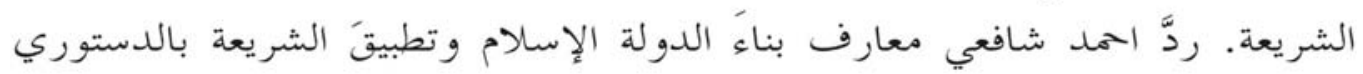
و الديموقرطي. ويَحذَف الشَصَ الذي يُعرِف التعبيرَ. سوى رؤية الدينية والتاريخية له له

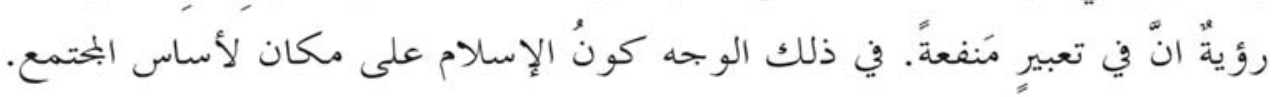

Keywords: negara Islam, Syariat Islam, etik dan Ahmad Syafii Maarif 


\section{A. Pendahuluan}

Wacana negara Islam dan formalisasi Syariat Islam di Indonesia kian merebak pasca tumbangnya rezim otoriter Orde Baru. Salah satu indikatornya dapat dilihat dari tumbuh suburnya kelompok-kelompok Islam radikal yang demikian getol mengusung formalisasi Syariat Islam. ${ }^{1}$ Selain itu, di ranah politik praktis, tercatat ada beberapa partai Islam semisal Partai Keadilan Sejahtera (PKS), Partai Bulan Bintang (PBB) dan Partai Persatuan Pembangunan (PPP) yang sempat bersemangat dalam memperjuangkan penerapan Syariat Islam di wilayah publik (negara). ${ }^{2}$ Fenomena politik lainnya yang mengindikasikan kegairahan sebagian kalangan Muslim Indonesia untuk menerapkan Syariat Islam di ranah publik adalah menjamurnya peraturan daerah (Perda) bernuansa Syariat Islam di beberapa daerah. $^{3}$

1 Kelompok-kelompok Islam radikal tersebut di antaranya adalah Hizbut Tahrir Indonesia (HTI), Laskar Jihad, Majelis Mujahidin Indonesia (MMI), Forum Umat Islam (FUI), Laskar Mujahidin, Gerakan Pemuda Islam, FKASWJ, Forum Betawi Rembug (FBR) dan Front Pembela Islam (FPI). Selain organisasi Islam radikal "level nasional" tersebut, tercacat juga organisasi berideologi serupa di "tingkat lokal", semisal Forum Pemuda Islam Surakarta, Komite Persiapan Penegakan Syari'at Islam di Banten, Gerakan Penegak Syari'at Islam di Yogyakarta, Lembaga Pengkajian Penerapan Syari'at Islam di Pamekasan, Lembaga Pengembangan dan Pengkajian Syari'at Islam di Sukabumi, dan Front Thoriqatul Jihad di Kebumen. Lihat Haedar Nashir, Gerakan Islam Syariat: Reproduksi Salafiyah Ideologis di Indonesia, Rizaluddin Kurniawan (ed.), (Jakarta: PSAP Muhammadiyah, 2007), hal. xii.

2 Keinginan menggebu-gebu partai-partai Islam untuk menggolkan formalisasi syariat Islam dapat dilihat dari desakan mereka untuk memasukkan kembali "tujuh kata sakral"(dengan kewajiban menjalankan syariat Islam bagi pemeluk-pemeluknya) ke dalam amandemen UUD 1945 yang dikenal dengan Piagam Jakarta (Jakarta Charter) di ranah legislatif. Namun upaya partai-partai Islam sampai detik ini senantiasa menuai kegagalan lantaran usulan tersebut ditolak sebagian besar anggota parlemen. Salah satu buku yang merekam dengan apik perdebatan para wakil rakyat dan sejumlah intelektual, baik yang pro maupun yang kontra terhadap formalisasi syariat Islam dapat dilihat dalam Ahmad Syafii Maarif, dkk, Syariat Islam Yes, Syariat Islam No: Dilema Piagam Madinah dalam Amandemen UUD 1945, (Jakarta: Paramadina, 2001).

3 Menurut hasil survei yang dilakukan UIN Syarif Hidayatullah Jakarta sebagaimana yang dimuat dalam majalah Gatra, 6 Mei 2006 tercatat sejak tahun 2001, aspirasi masyarakat menuntut penerapan syariat Islam dari tahun ke tahun kian meningkat. Pada 2004, responden yang menghendaki penerapan syariat Islam dituangkan dalam aturan pemerintah mencapai 75,5\%. Selain Aceh, tuntutan formalisasi syariat Islam datang dari Sulewasi Selatan, Provinsi Banten, Riau, dan beberapa kabupaten seperti Cianjur, Mataram, dan Pamekasan. Bahkan, di Kabupaten Bulukamba, eksperimen syariat Islam telah berlangsung sejak 1995 dan hingga 2005, Perda syariat Islam yang dihasilkan telah mencakup permasalahan: minuman keras; zakat, infaq, dan sadaqah; bisa membaca Al-Qur'ân bagi siswa dan calon pengantin; dan kewajiban mengenakan busana Muslim bagi seorang Muslim dan Muslimah. 
Setidaknya ada tiga alasan yang dikemukakan oleh pengusung negara Islam dan formalisasi Syariat Islam di Indonesia. Pertama, secara teologis mereka mengimani bahwa terdapat doktrin Islam yang memuat perintah penerapan Syariat Islam. ${ }^{4}$ Hanya dengan menjadikan Islam sebagai dasar negara, Syariat Islam dapat ditegakkan. Kedua, Islam dan negara tidak ada pemisahan (ad-dîn wa as-siyâsab). ${ }^{5}$ Islam merupakan agama yang meliputi semua dimensi kehidupan yang tidak dapat dipisah-pisahkan (kâffah; wholeness). ${ }^{6}$ Argumen mereka tersebut selain dinisbatkan pada doktrin teologis, juga berdasar pada keyakinan historis bahwa nabi Muhammad SAW pernah menjadi pemimpin agama sekaligus pemimpin negara. ${ }^{7}$ Ketiga, mereka meyakini bahwa hanya dengan diberlakukannya Syariat Islam, bangsa Indonesia akan mampu keluar dari semua krisis multidimensional. ${ }^{8}$ Selain itu, bagi mereka tuntutan formalisasi Syariat Islam merupakan raison d'etre atas gagalnya pemerintah Indonesia menegakkan hukum dan kriminalitas. ${ }^{9}$ Mereka acapkali melakukan

4 Menurut mereka, kewajiban teologis tentang penerapan syariat Islam didasarkan pada Q.S. al-Mâidah: 44-47 yang terjemahannya kurang lebih "Barangsiapa tidak memutuskan perkara menurut apa yang diturunkan Allah, maka mereka itu kafir...zalim...fasik". Lihat Adian Husaini, "Syariat Islam di Indonesia: Problem Masyarakat Muslim Kontemporer", Tashwirul Afkar, Edisi No. 12 Tahun 2002, hal. 62-64.

5 Yusuf al-Qardawi, Figh Negara, alih bahasa Syafri Hakim, (Jakarta: Robbi Press, 1987), hal. 44-47. Lihat pula artikel Khamami Zada, "Wacana Syariat Islam: Menangkap Potret Gerakan Islam di Indonesia”, Tashwirul Afkar, Edisi No. 12 Tahun 2002, hal. 33.

6 Selain Q.S. al-Mâidah: 44-47, menurut pengusung formalisasi syariat berpijak pada Q.S. al-Baqarah: 208. Terjemahannya sebagai berikut: "Wahai Orang-orang yang beriman, masuklah kalian ke dalam Islam secara kâffah dan janganlah kalian ikuti langkah-langkah setan karena sesunggubnya setan adalah musub yang nyata bagimu”. Departemen Agama, Al-Qur'ân dan Terjemahnya, (Jakarta: Proyek Pengadaan Kitab Suci Al-Qur'ân, 1983), hal. 167-168. Pandangan yang mengatakan bahwa Islam adalah agama yang menekankan "keserbamenyeluruhan" (wholeness) berbasis pada "paradigma taubidi". Lihat Azyumardi Azra, Konflik Baru Antar Peradaban Globalisasi, Radikalisme, dan Pluralisme, (Jakarta: PT Raja Grafindo Persada, 2002), hal. 6.

Keyakinan historis ini sejatinya lebih merupakan derivasi dari konsep Islam sebagai ad-dîn wa as-siyâsah. Fakta historis menunujukkan di samping nabi menjadi pemimpin agama, nabi menjadi pemimpin politik (negara). Moch. Nur Ichwan, "Ulama and Politics", dalam Noorhaidi Hasan, dkk., Moving with the Times: the Dynamics of Contemporary Islam in a Changing Indonesia, (Moch. Nur Ichwan \& Noorhaidi Hasan (eds.)), (Yogyakarta: CISform UIN Sunan Kalijaga), hal. 91.

Argumen ini merupakan argumen yang bersifat situasional. Menurut keyakinan mereka krisis multidimensional yang mendera bangsa Indonesia lantaran bangsa ini enggan menerapkan syariat Islam, namun sebaliknya menerapkan sistem sekuler. Bagi mereka, penerapan syariat Islam akan menjadi panacea, obat mujarab yang dapat menuntaskan segala krisis bangsa. Lihat Muhammad Ismail Yusanto, "Selamatkan Indonesia dengan Syariat Islam", dalam Arskal Salim dkk., Syariat Islam..., hal. 139-171.

Arskal Salim dan Azyumardi Azra, "Negara dan Syariat dalam Perspektif Politik Hukum Indonesia" dalam Arskal Salim, dkk., Syariat Islam Pandangan Muslim Liberal, Burhanuddin (ed.), (Jakarta: Jaringan Islam Liberal-The Asia Foundation, 2003), hal. 79-80. 
tindakan main hakim sendiri karena aparat penegak hukum membiarkan atau tidak cukup mampu membasmi berbagai kemaksiatan.

Keinginan sebagian kalangan untuk menjadikan Islam sebagai dasar negara sesungguhnya bukanlah fenomena yang baru. Ia telah mencuat sejak Indonesia masih berumur belasan bulan, tepatnya ketika penentuan dasar negara. Akan tetapi, tuntutan yang didendangkan kelompok Islam tersebut kandas di tengah jalan lantaran mendapatkan resistensi dari kelompok nasionalis. ${ }^{10}$ "Kekalahan diplomatis" tersebut tidak menyurutkan sebagian kalangan Muslim untuk terus memperjuangkan Islam sebagai dasar negara dan memformalisasikan Syariat Islam hingga detik ini, baik lewat jalur parlemen maupun gerakan di luar parlemen sebagaimana yang telah dilakukan oleh berbagai kelompok Islam radikal seperti FPI, MMI, FUI, dan lain-lain selama ini.

Fenomena menguatnya wacana negara Islam dan formalisasi Syariat Islam di Indonesia merupakan suatu fenomena sosio-politik-keagamaan yang menggembirakan sekaligus problematis. Membanggakan lantaran menguatnya wacana negara Islam dan formalisasi Syariat Islam menandakan bahwa sebagian umat Islam Indonesia sedang mengalami kegairahan dalam beragama (Islam). Problematis dikarenakan wacana negara Islam dan formalisasi Syariat Islam akan mengancam keutuhan (baca: disintegrasi) Negara Kesatuan Republik Indonesia (NKRI) yang berideologi Pancasila dan berdasar UUD 1945. Alasannya, Pancasila yang telah didaulat menjadi ideologi negara sejak berdirinya nation state bernama Indonesia yang diproklamasikan the founding fathers, Soekarno-Hatta pada 17 Agustus 1945 akan terancam eksistensinya lantaran munculnya wacana negara Islam dan formalisasi Syariat Islam ditengarahi hanya akan berujung pada pembabatan pluralitas bangsa, pelanggaran Hak Asasi Manusia (HAM), dan pengebirian nilai-nilai demokrasi. ${ }^{11}$

Selain mendapatkan tantangan dan penolakan yang serius dari kelompok nasionalis, keinginan kelompok Islam untuk menjadikan Islam sebagai dasar bangsa dan formalisasi Syariat Islam juga mendapatkan resistensi yang luar biasa dari umat beragama non-Muslim, terutama kelompok Kristen. ${ }^{12}$ Di kalangan umat Islam di

10 Ahmad Syafii Maarif, Islam dan Masalab Kenegaraan: Studi tentang Percaturan dalam Konstituante, (Jakarta: LP3ES, 1985), hal. 101-110.

11 Zuhairi Misrawi, "Dekonstruksi Syariat: Jalan Menuju Desakralisasi, Reinterpretasi, dan Depolitisasi”, Tashwirul Afkar, Edisi No. 12 Tahun 2002, hal. 12-14. Studi tentang kontraproduktivitas penerapan syariat Islam di negara-negara lain dapat pula dibaca pada tulisan Saiful Mujani, "Syariat Islam dalam Perdebatan", dalam Arskal Salim dkk., Syariat Islam..., hal. 19-51.

12 Sigit Kamseno, "Komprehensivisme Dîn al-Islâm: Kritik atas Konsep Kulturalisme dan Strukturalisme Islam”, Jurnal Politik Islam, Vol. 1, No. 2, 2006, hal. 164. 
Indonesia sendiri, upaya mewacanakan negara Islam dan praktik formalisasi Syariat Islam menuai penolakan dari organisasi Islam seperti Nahdlatul Ulama (NU) dan Muhammadiyah, dua organisasi massa Islam terbesar di Indonesia. Dua ormas Islam ini menempati garda terdepan dalam menolak setiap upaya formalisasi Syariat Islam. ${ }^{13}$

Sementara dalam konteks personal, terdapat banyak tokoh dan intelektual Islam Indonesia yang berkeberatan apabila Islam dijadikan dasar negara dan formalisasi Syariat Islam. Salah satunya adalah Ahmad Syafii Maarif. ${ }^{14}$ Sebagai salah

13 Ahmad Syafii Maarif, "Menawarkan Substansi Syariat Islam", wawancara Zuhairi Misrawi dengan Ahmad Syafii Maarif, Tashwirul Afkar, Edisi No. 12 Tahun 2002, hal. 105-110.

14 Ahmad Syafii Maarif yang akrab dipanggil Buya Ahmad Syafii Maarif dilahirkan di Calau, Sumpur Kudus, Sumatera Barat, pada 31 Mei 1935. ${ }^{15}$ Pendidikan formal Buya Syafii Maarif dimulai dari tingkat dasar yaitu Sekolah Rakyat (SR) dan Madrasah Ibtidaiyah Sumpur Kudus (lulus 1947), kemudian ia melanjutkan ke tingkat menengah pertama pada Madrasah Muallimin di Balai Tangah, Lintau, Sumatera Barat (1950-1953). Setelah itu, ia pindah ke Yogyakarta untuk melanjutkan pendidikan menengahnya di Mualimin Muhammadiyah (lulus pada 1956). Ia lantas hijrah ke Solo untuk meneruskan pendidikan di Universitas Cokroaminoto dan menggondol gelar Sarjana Muda Sejarah Budaya pada 1964. Selanjutnya, ia sukses memperoleh Gelar Sarjana Sejarah dari IKIP Yogyakarta (kini Universitas Negeri Yogyakarta) pada 1968. Ia kemudian memperdalam Ilmu Sejarah dengan mengikuti program master di Departemen Sejarah Universitas Ohio, Amerika Serikat pada 1976 dengan beasiswa Fulbright. Ia berhasil mengantongi ijazah master pada 1980. Atas jasa Amien Rais yang telah memperkenalkan dan memintakan rekomendasi kepada Fazlur Rahman, Ahmad Syafii Maarif diterima di Universitas Chicago, dan berhasil mendapatkan gelar doktor pada program studi Bahasa dan Peradaban Timur Dekat. Selama kuliah di Chicago, Ahmad Syafii Maarif secara intensif juga aktif melakukan pengkajian Al-Qur'ân yang dibimbing langsung oleh gurunya sekaligus tokoh pembaharu pemikiran Islam, Fazlur Rahman. Di Universitas ternama itu pula, Tokoh yang mengaku pernah menjadi simpatisan berat Masyumi ini kerap terlibat diskusi dengan beberapa tokoh Indonesia seperti almarhum Nurcholish Madjid dan Amien Rais yang saat itu juga sedang menempuh program doktor. Sebagian besar aktivitas yang pernah dilakoni Buya Ahmad Syafii Maarif bergelut di dunia akademik. Berbagai aktivitas akademik itu, misalnya, mengajar di PGA Muhammadiyah di Lombok Timur selama satu tahun (1956-1957), menjadi asisten dosen untuk mata kuliah Sejarah Indonesia Kuno di FKIS IKIP Yogyakarta (kini Universitas Negeri Yogyakarta) dan asisten Sejarah Islam di Universitas Islam Indonesia (UII) Yogyakarta pada 1967. Ia dikukuhkan sebagai Guru Besar Filsafat Sejarah di Universitas Negeri Yogyakarta pada tahun 1997. Ia sempat mengajar di Program Pascasarjana UIN Sunan Kalijaga Yogyakarta. Pada 1986, Ahmad Syafii Maarif pernah menjadi profesor tamu di Universitas Iowa, Amerika Serikat. Tahun 1993-1994 pernah menjadi profesor madya tamu di Institute of Islamic Studies, Universitas McGill. Ia juga pernah tercatat sebagai dosen tamu untuk mengajar mata kuliah Sejarah Perang Salib dan Islam dan Perubahan Sosial di Asia Tenggara di Universitas Kebangsaan Malaysia (1990-1992). Selain itu, ia pernah menjadi anggota Kelompok Pemikir Masalah Agama Departemen Agama pada 1984. Buya Ahmad Syafii Maarif dikenal sebagai seorang intelektual yang berkontribusi dalam mempopulerkan gagasan pembaharuan Islam di Indonesia. Ia sangat berjasa dalam mendorong gerbong pemikiran Islam yang inklusif dan toleran. Gagasan-gagasan pembaharuannya acapkali membuat "kebakaran jenggot" banyak kalangan Muslim, sehingga tidak jarang ia dilabeli munafik, agen zionis, dan 
satu intelektual Muslim terkemuka dan berpengaruh di Indonesia, tentu saja pandangan-pandangannya tentang relasi agama (Islam) dan negara menemukan momentumnya di saat bangsa ini banyak dibelit berbagai problematika, terutama terkait masalah ideologi negara. Karenanya, penulis memandang penting untuk mengetengahkan dan mengkaji pemikiran Ahmad Syafii Maarif yang moderat, inklusif, dan substansialistik.

\section{B. Relasi Islam dan Negara}

Hubungan Islam dan negara (politik) sepertinya tidak pernah habis untuk diperbincangkan. Hingga sekarang, wacana tentang perlu tidaknya agama mewarnai kehidupan negara - dalam berbagai bentuknya - masih terus menuai pro dan kontra. Ada banyak kalangan yang menghendaki Islam dijadikan dasar negara, namun

stereotip jelek lainnya. Menanggapi pendapat miring tersebut, ia tidak ambil pusing dan menganggapnya sebagai resiko intelektual. Ia juga pernah aktif dalam berbagai organisasi semisal menjadi anggota Muhammadiyah (1955), anggota HMI (1957-1968), Pengurus HMI Cabang Surakarta (1963-1964), Pejabat Sementara Ketua Umum Pimpinan Pusat (PP) Muhammadiyah, dan menjabat Ketua Umum PP Muhammadiyah selama tujuh tahun (1998-2005). Tokoh yang dikenal low profile dan bersahaja ini pernah dipercaya menjadi salah satu presiden International of World Conference on Religion for Peace, sebuah institusi keagamaan internasional yang anggotanya terdiri dari berbagai tokoh lintas agama yang concern dan getol mempromosikan perdamaian. Pada 28 Februari 2003 di Jakarta, ia mendirikan Maarif Institute for Culture and Humanity, sebuah lembaga yang concern terhadap isu-isu keislaman dan demokrasi. Kelahirannya bermula dari kesadaran akan pentingnya institusi kultural yang memperjuangkan tersosialisasikannya watak dan ciri khas Islam Indonesia sebagai agama rahmatan li al-âlamîn, inklusif, dan toleran serta memiliki kesesuaian dengan demokrasi yang berpihak kepada keadilan. Tahun 2008, ia menerima Magsaysay Award 2008 dari The Board of Trustees of the Ramon Magsaysay Foundation (RMAF). Ia meraih Magsaysay Award 2008 dalam kategori Peace and International Understanding. Buya Syafii Maarif menerima penghargaan prestisius tersebut karena komitmen dan kesungguhannya membimbing umat Islam untuk meyakini dan menerima toleransi dan pluralisme sebagai basis untuk keadilan dan harmoni di Indonesia bahkan dunia. Ahmad Syafii Maarif, Titik-Titik Kisar Di Perjalananku: Otobiografi Abmad Syafii Maarif, (Yogyakarta: Penerbit Ombak-Maarif Institute, 2006), hal. 71 dan 189. Wawancara dengan Ahmad Syafii Maarif pada 12 Januari 2009. Dan RMAF merupakan lembaga internasional yang didirikan pada April 1957 di Manila, dan sejak 1958 memberi penghargaan kepada individu dan lembaga di Asia tanpa memandang suku, jenis kelamin, kewarganegaraan dan agama. Buya Syafii Maarif merupakan putra kedua Indonesia yang menerima penghargaan pada kategori "Peace and International Understanding" ini setelah Soedjatmoko menerimanya pada 1978. Putra Indonesia lainnya penerima Magsaysay award adalah Mochtar Lubis dan Pramudya Ananta Toer untuk Journalism, Literature, and Creative Communication Arts, Abdurrahman Wahid untuk Community Leadership, dan Dita Indah Sari untuk kategori Emergent Leadership, dikutip dari http $/ /$ www.antara.co.id $=$ arc $=2008=7=31=\mathrm{ahmad} / \mathrm{syafii} / \mathrm{maarif} /$ terima/magsaysay/ award.htm/acces sed 3 Januari 2009. 
tidak sedikit pula yang menginginkan Islam sebatas spirit dan penjaga moral-etik dalam bernegara. Masing-masing pihak memiliki argumentasinya sendiri-sendiri.

Dalam kesempatan ini, penulis akan mendedahkan pandangan Ahmad Syafii Maarif tentang hubungan Islam dan negara. Diskusi mengenai tema ini mencakup dua aspek, yakni aspek normatif dan aspek historis. Dengan mendiskusikannya, diharapkan dapat memperjelas bagaimana sesungguhnya relasi Islam dan negara.

\section{Tinjauan Normatif}

Menurut Ahmad Syafii Maarif, secara doktrinal, Islam tidak menetapkan dan menegaskan pola apapun tentang teori negara Islam yang wajib digunakan oleh kaum Muslim. H.A.R. Gibb seperti dikutip Buya Ahmad Syafii Maarif, memaparkan bahwa baik Al-Qur'ân maupun Sunnah tidak memberikan petunjuk yang tegas tentang bentuk pemerintahan dan lembaga-lembaga politik lainnya sebagai cara bagi umat untuk mempertahankan persatuannya. ${ }^{15}$

Terminologi "kerajaan Islam", "kesultanan Islam" atau "monarkhi Islam" menurut Buya Syafii Maarif sebenarnya bersifat kontradiktif di dalamnya. Monarkhi, kesultanan, dan seterusnya tidak secara otomatis dapat menjadi Islam kendatipun menggunakan embel-embel nama Islam. Ia juga mengkritik gagasan negara Islam. Menurutnya, gagasan negara Islam tidak memiliki basis religio-intelektual yang kukuh, yang berbicara secara teoretik. Terminologi negara Islam tidak ada dalam kepustakaan Islam klasik. Dalam Piagam Madinah pun, terminologi ini tidak ditemukan. ${ }^{16}$ Gagasan negara Islam (daulatul-islâmiyyah), menurutnya, merupakan fenomena abad ke-20. Kendati demikian, Islam sangat membutuhkan mesin negara untuk membumikan cita-cita dan ajaran-ajaran moral. ${ }^{17}$ Al-Qur'ân yang penuh dengan ajaran imperatif moral, lanjutnya, tidak diragukan lagi sangat membutuhkan negara sebagai institusi "pemaksa" bagi pelaksanaan perintah dan ajaran moralnya. ${ }^{18}$

Argumentasi Buya Syafii Maarif ini berangkat dari asumsi bahwa Islam bukanlah sekedar cita-cita moral dan nasihat-nasihat agama yang lepas begitu saja. Islam membutuhkan sarana sejarah untuk mewujudkan cita-cita moralnya yang mencakup seluruh aspek kehidupan. Sarana yang dimaksud Buya Ahmad Syafii Maarif tidak

15 Ahmad Syafii Maarif, Islam dan Masalah..., hal. 20.

16 Wawancara dengan Ahmad Syafii Maarif pada 12 Januari 2009.

17 Ahmad Syafii Maarif, Islam: Kekuatan Doktrin dan Kegamangan Umat, (Yogyakarta: Pustaka Pelajar, 1997), hal. 60-62. Penjelasan yang sama juga diberikan pada saat penulis mewancarainya.

18 Ahmad Syafii Maarif, Islam dan Politik: Teori Belab Bambu Masa Demokrasi Terpimpin (1959-1965), (Jakarta: Gema Insani Press, 1996), hal. 193. 
lain adalah negara. Oleh karenanya, ia menolak pandangan yang menghendaki pemisahan Islam dan negara. Menurutnya, di samping tidak memiliki basis teoretis yang kuat, pendapat seperti itu dalam waktu yang panjang akan berakhir menjadi kerja bunuh diri.

Buya Ahmad Syafii Maarif menganggap bahwa semua aspek kehidupan tidak dapat ditempatkan dalam kategori yang dikotomis, antara ibadah dan kerja sekuler. ${ }^{19}$ Dalam hal ini, ia sepakat dengan pandangan Ibnu Taimiyyah dalam kitab as-siyâsi as-syar'iyyah yang mengemukakan bahwa negara (kekuasaan politik) merupakan sesuatu yang penting bagi agama. Tanpa adanya negara, agama tidak akan tegak dengan kukuh. Ibnu Taimiyyah menuturkan bahwa Allah mewajibkan amar ma'ruf nahî munkar, jihad, keadilan, menegakkan budûd, dan semua hal yang Allah wajibkan. Hal itu tidak mungkin terealisasi dengan sempurna tanpa kekuatan dan kekuasaan. ${ }^{20}$

Menariknya, sekalipun menyerukan pentingnya negara bagi Islam, tetapi Buya Ahmad Syafii Maarif menolak tesis yang mengatakan bahwa Islam adalah dîn dan daulâh. Sebagaimana telah penulis singgung di muka, tidak ditemukan landasan yang kuat bahwa Islam adalah dîn dan daulâh, baik di dalam Al-Qur'ân, Hadis, maupun Piagam Madinah. Apabila Islam merupakan dîn sekaligus daulâh, maka secara otomatis menempatkan sejajar antara agama dengan negara. Dengan demikian mereka yang meyakini Islam sebagai dîn sekaligus daulâh secara tidak sadar menempatkan alat dengan risalah. Ia menilai tesis yang mengatakan bahwa Islam itu agama sekaligus negara sebagai kekeliruan serius. Hal ini lantaran agama adalah sesuatu yang immutable (tetap), sementara negara adalah sesuatu yang mutable (berubah) sesuai dengan tuntutan ruang dan waktu. Dengan menempatkan negara selevel dengan posisi negara berarti mereka mengagungkan negara sama halnya dengan mengagungkan agama. ${ }^{21}$ Inilah yang menjadi kekhawatiran Ahmad Syafii Maarif.

Menurut Buya Ahmad Syafii Maarif, posisi Nabi Muhammad dalam Al-Qur'ân hanyalah sebagai Rasul. Kendatipun tak dapat dipungkiri dalam rekaman historis, beliau pernah menjadi pemimpin agama sekaligus pemimpin negara. Posisinya sebagai Rasul Allah tidak pernah berubah sampai beliau wafat pada $632 \mathrm{M}$. Kedudukan Nabi Muhammad sebatas Rasul Allah termaktub juga dalam Q.S. Surat

19 Ahmad Syafii Maarif, Islam dan Politik..., hal. 194.

20 Ibid., hal. 133.

21 Ibid., hal. 195-196. 
Ali Imran: 144. Statemen Al-Qur'ân bahwa "Muhammad hanyalah seorang Rasul” inilah yang kemudian yang dijadikan argumentasi Buya Ahmad Syafii Maarif untuk menolak tesis bahwa "Islam adalah agama dan negara". Bagi Buya Syafii Maarif, tesis bahwa "Islam merupakan agama dan negara" mengaburkan hakikat yang sebenarnya dari posisi kenabian Muhammad SAW. ${ }^{22}$

Perspektif Buya Ahmad Syafii Maarif tentang relasi Islam dan negara di atas pastinya berseberangan dengan pendapat para pengusung negara Islam dan formalisasi Syariat Islam. Hal ini karena bagi mereka, Islam adalah agama sekaligus

merupakan perintah Tuhan yang wajib dilakukan dan dipandang sebagai amal saleh. ${ }^{23}$ Hal ini misalnya dapat ditilik dari pernyataan Muhammad Ismail Yusanto, Juru Bicara HTI, yang menganggap pendirian negara Islam sebagai tuntutan akidah Islam. ${ }^{24}$

Pandangan semacam ini dapat pula ditemukan pada pemikiran Sayyid Qutb mengenai konsep hâkimiyyat Allâh. Konsep Sayyid Qutb ini mirip dengan pendapat al-Maududi bahwa kedaulatan tertinggi milik Allah sebagaimana penulis telah singgung di awal. Hâkimiyyat Allâh merupakan konsep pengakuan akan otoritas Tuhan dan Syariat-Nya semata di atas muka bumi dan ketertundukan manusia hanya kepada-Nya. ${ }^{25}$ Konsekuensinya, manusia harus menerima kedaulautan Tuhan tersebut secara taken for granted. Tidak ada sedikitpun ruang bagi manusia untuk berkreasi. Karenanya, sangat mudah dinalar jikalau mereka menolak sistem demokrasi lantaran ia dianggap bukan ciptaan Tuhan dan (terlebih lagi) berasal dari Dunia Barat yang sekuler.

\section{Tinjauan Historis}

Mendiskusikan relasi Islam dan negara tidak pernah lepas dari sejarah kenabian Muhammad SAW. Tak dapat dipungkiri -sebagaimana penulis sebutkan di mukaNabi Muhammad SAW merupakan pemimpin agama sekaligus pemimpin negara. Hal ini tampak ketika beliau menjadi pemimpin di Madinah. Beliau sendiri tidak pernah menyebut dirinya sebagai penguasa. ${ }^{26}$ Nabi Muhammad SAW juga tidak

22 Ahmad Syafii Maarif, Islam dan Masalah.., hal. 14-15.

23 Adian Husaini, "Syariat Islam di Indonesia..., hal. 65.

24 Muhammad Ismail Yusanto, "Selamatkan Indonesia dengan Syariat Islam", dalam Burhanuddin (ed.) dkk., Syariat Islam..., hal. 145.

25 Zaenul Ma'arif, "Menggali Akar Fundamentalisme Islam: Paradigma Sebagai Pisau Analisis", dikutip dari http://islamlib.com/id/index.php?page=article\&id=74/accessed 18 Desember 2006.

26 Wawancara dengan Ahmad Syafii Maarif pada 12 Januari 2009. 
pernah mendeklarasikan sistem atau bentuk pemerintah yang baku yang harus dianut oleh umat Islam. Ini menunjukkan bahwa beliau adalah seorang pemimpin yang visioner dan futuristik. Beliau memahami betul bahwa masyarakat Muslim adalah masyarakat yang pluralistik dan dinamis. Apabila hanya ada satu bentuk atau sistem pemerintahan yang harus diimani oleh umat Muslim, maka secara politis akan menyulitkan umat Islam itu nantinya. Sebab, umat Muslim di satu negara dengan negara yang lain memiliki mekanisme politik yang beragam.

Mekanisme politik yang beragam ini dapat disimak dari sejarah kepemimpinan kbulafa ar-râsyidîn. Pasca wafatnya Nabi Muhammad SAW, umat Muslim mengalami krisis kepemimpinan. Fazlur Rahman sebagaimana dikutip Ahmad Syafii Maarif menyebutnya sebagai krisis konstitusional. ${ }^{27}$ Terlambatnya pemakaman jenazah nabi merupakan indikator akan gawatnya krisis kepemimpinan pada saat itu. ${ }^{28}$ Umat Islam mengalami kebingungan karena Nabi tidak meninggalkan pesan siapa pengganti beliau. Kemudian atas konsensus para petinggi Islam di Balai Banu Sa’idah, ditunjuklah Abu Bakar sebagai pengganti nabi. Pertemuan di Balai Banu Sa'idah menurut Buya Syafii Maarif menjadi titik tolak yang sangat penting dalam sejarah politik Islam pada periode awal. Pertemuan tersebut, kata Buya Syafii Maarif, dapat dikatakan sebagai pelaksanaan syûrâ pertama di kalangan umat Muslim pasca wafatnya Nabi. ${ }^{29}$

Saat pengangkatan Abu Bakar ini, muncul clash of interest antara mayoritas pemuka Islam dengan Ali bin Abi Thalib beserta pengikutnya. Ali dan kelompoknya mengklaim diri sebagai pemimpin yang paling berhak menggantikan nabi karena khilafah menurut mereka adalah miraa un nubuwwah, keluarga Nabi Muhammad SAW lebih berhak memperoleh miraa ini. Karena beberapa alasan, Ali disingkirkan dari percaturan politik dan mayoritas pemuka Islam lebih memilih Abu Bakar secara aklamasi sebagai khalifah. ${ }^{30}$

Sepeninggal Abu Bakar, estafet kekhalifahan dipegang oleh Umar bin Khattab melalui wasiat yang diberikan oleh Abu Bakar. Pasca Umar bin Khattab lengser keprabon, jabatan khalifah dikuasakan kepada Ustman bin Affan melalui tim formatur yang diprakarsai Umar. Pasca Ustman mangkat, posisi kekhalifahan dijabat oleh Ali melalui aklamasi. Periode keempat khalifah ini terkenal dengan sebutan

27 Ahmad Syafii Maarif, Islam dan Masalah..., hal. 19.

28 Ibid., hal. 21.

29 Ibid.

30 Jalaluddin Rakhmat, Islam Alternatif, (Bandung: Mizan, 1986), hal. 250. 
khulafa ar-râsyidîn. ${ }^{31}$ Ketidakbakuan sistem kepemimpinan pada masa khalifah menandakan bahwa sistem khilafah muncul untuk merespons kondisi pada waktu itu dan sifatnya ad hoc.

Pasca periode khulafa ar-râsyidîn, terjadi transformasi yang sangat mendasar dalam sistem politik pada periode Bani Umayyah dan Bani Abbasiyyah. Berbeda dengan periode sahabat, sistem khilafah pada periode ini dijalankan secara dinasti oleh keluarga kerajaan. Hal ini berlanjut sampai dengan masa khilafah Usmaniyyah (Ottoman Empire). Di masa ini, khilafah pernah menjadi pusat perdagangan dan investasi. Turki Utsmani memperbolehkan pedagang Eropa mengakses pelabuhannya dengan syarat membayar bea cukai. Tidak sedikit pula rute perdagangan penting dari seluruh dunia yang melewati wilayah Turki Utsmani. Aktivitas ekonomi di Turki Utsmani ketika itu tumbuh pesat karena ia berada pada jalur persimpangan Afrika, Asia, dan Eropa. ${ }^{32}$

Singkatnya, sistem khilafah Islamiyah sempat eksis dan berkuasa selama kurang lebih 13 abad lamanya, terhitung sejak masa khulafa ar-râsyidîn pada $632 \mathrm{M}$ hingga masa Turki Utsmani yang berakhir pada tahun 1924 M. Rentang waktu selama itu, tak dapat dipungkiri sistem khilafah pernah menjadi kekuatan politik, ekonomi, dan militer yang dominan. Kalangan yang memimpikan formalisasi Syariat Islam kerapkali mengklaim semua model pemerintahan tersebut sebagai prototipe pemerintahan yang harus diadopsi sebagai sebuah "formula Islami". ${ }^{33}$ Romantisme sejarah kejayaan Islam pada masa khalifah inilah salah satu yang melatar belakangi sebagian kalangan Muslim untuk menjadikan Islam sebagai dasar negara atau mendirikan negara Islam. ${ }^{34}$

Apabila diamati lebih jauh, "kesuksesan" masa kekhalifahan bisa dibilang tidak berlangsung lama. Muhammad Said al-Asymawi mengemukakan bahwa

31 Salah satu buku yang secara komprehensif menjelaskan model kepemimpinan politik Islam di era khulafa al-rasyidîn dapat dibaca dalam buku karya Munawwir Sjadzali, Islam dan Tata Negara: Ajaran, Sejarah, dan Pemikiran, (Jakarta: UI Press, 1990), hal. 21-33. Lihat juga artikel A. Qodri Azizy, "Agama dalam Bernegara", Bagian Pertama dari Dua Tulisan, Republika, Selasa 14 Agustus 2007.

32 Rosi Selly, "Kebangkitan Khilafah Islamiyah di Tengah Arus Global", Jurnal Politik Islam, volume I, nomor 2, 2006/1427, hal. 171-172.

33 Abdurrahman Wahid, Islamku Islam Anda Islam Kita: Agama Masyarakat Negara Demokrasi (Jakarta: The Wahid Institute, 2006), hal. 83.

34 Jajang Jahroni, "Khilafah Islam: Khilafah yang Mana?" dalam Abd. Moqsith Ghazali, dkk., Ijtihad Islam Liberal: Upaya Merumuskan Keberagamaan yang Dinamis (Jakarta: Jaringan Islam Liberal, 2005), hal. 85-87. 
keberhasilan sistem khilafah dalam menciptakan situasi politik yang "demokratis" hanya terjadi sebentar pada masa Umar bin Khattab dan sebentar di masa Umar bin Abdul Azis. Masa itu teramat pendek, kira-kira sekitar 22 tahun saja dari rentang panjang sejarah Islam yang berumur 14 abad lebih..$^{35}$ Karenanya, dapat dikatakan mereka yang mengidealkan formalisasi Syariat Islam sesungguhnya lebih didasari atas romantisme (backward looking) ke masa kekhalifahan pada periode awal Islam tanpa dibarengi dengan sikap kritis terhadap sistem tersebut.

Dalam sejarah Indonesia, kalangan yang menghendaki Islam sebagai dasar negara Indonesia beralasan bahwa Indonesia merupakan negara yang dihuni oleh mayoritas Muslim. Hal ini misalnya dapat dilihat dari pernyataan Muhammad Natsir tentang relasi Islam dan negara. Natsir di depan Majelis Konstituante menginginkan Islam menjadi dasar negara karena pemeluk mayoritas bangsa ini Muslim. Dalam pidatonya tersebut, Natsir berdalil bahwa untuk dasar negara, Indonesia hanya memiliki dua pilihan, yakni sekulerisme (lâ dîniyyah) atau paham agama (dîni). Natsir menganggap Pancasila sebagai dasar negara yang sekuler karena Pancasila bercorak lâ-dîniyyah. ${ }^{36}$ Bagi Natsir, negara sebagai kekuatan dunia merupakan sesuatu yang mutlak dalam Al-Qur'ân. Hanya dengan adanya kekuasaan politik (negara), aturan-aturan dan ajaranajaran Islam dapat diimplimentasikan dalam kehidupan nyata. Karenanya, Natsir membela prinsip persatuan agama dan negara. ${ }^{37}$

Menurut Buya Ahmad Syafii Maarif, aspirasi menjadikan Islam sebagai dasar negara yang dilakukan para tokoh Islam di masa kemerdekaan jika dikaji lebih mendalam sesungguhnya tidak jelas aspirasi Islam yang diperjuangkannya. Di matanya, tidak gambang menempatkan Syariat Islam ke dalam mekanisme kehidupan politik modern. Ia mencontohkan Pakistan sebagai negara Islam yang sampai sekarang masih bingung menerapkan Syariat dalam kehidupan kenegaraannya. Dalam konteks ini, ia mengkritik para tokoh Islam masa lampau yang menurutnya lebih mengutamakan wadah, yaitu menegakkan negara berdasarkan Islam secara formal. ${ }^{38}$

35 Muhammad Said al-Asymawi, "Jalan Menuju Tuhan" dalam Burhanuddin (ed.), dkk., Syariat Islam..., hal. 3.

36 Ahmad Syafii Maarif, Islam dan Masalah..., hal. 127.

37 Ahmad Syafii Maarif, "Islam di Masa Demokrasi Liberal dan Demokrasi Terpimpin", Prisma No. 5, Tahun XVIII, 1988, hal. 26.

38 Anonim, "Umat Islam Seribu Tahun Berhenti Berpikir", wawancara Prisma dengan Ahmad Syafii Maarif. Prisma No. 4, April 1984, Tahun XII, hal. 68. 


\section{Islam dan Landasan Etik Bernegara}

Menurut Buya Ahmad Syafii Maarif, Islam tidak mempermasalahkan apapun nama dan bentuk pemerintahan, Islam hanya menekankan pentingnya moral-etik dalam kehidupan bernegara. ${ }^{39}$ Al-Qur'ân tidak memberikan suatu pola teori atau sistem yang pasti, yang harus diikuti oleh umat Islam. Hal ini Pertama, Al-Qur'ân pada prinsipnya merupakan petunjuk etik bagi manusia, ia bukanlah kitab ilmu politik. Kedua, institusiinstitusi sosio-politik dan organisasi manusia senantiasa berubah dari masa ke masa. Dengan kata lain, diamnya Al-Qur'ân dalam masalah ini dapat diartikan bahwa Al-Qur'ân memberikan suatu jaminan yang sangat esensial bagi manusia untuk mencari sistem yang tepat. Tujuan terpenting Al-Qur'ân dan juga Islam adalah supaya nilai-nilai dan perintah-perintah etiknya dijunjung tinggi dan bersifat mengikat terhadap kegiatan-kegiatan sosio-politik umat Islam. Nilainilai tersebut secara perenial, integral dengan prinsip-prinsip keadilan, persamaan, dan kemerdekaan yang kesemuanya itu menempati posisi sentral dalam ajaran moral Al-Qur'ân. ${ }^{40}$

Sebagai suatu petunjuk bagi umat manusia, Al-Qur'ân menurut Ahmad Syafii Maarif menyediakan suatu fondasi yang kukuh dan tak berubah bagi semua prinsip etik dan moral bagi kehidupan ini. Al-Qur'ân memperlakukan kehidupan manusia sebagai suatu keseluruhan yang organik dan integralistik yang semua bagianbagiannya harus dibimbing oleh petunjuk dan perintah-perintah etik dan moral yang bersumber pada kitab ini. ${ }^{41}$

Untuk merealisasikan segenap ajaran Islam, sebagaimana telah penulis sebutkan di atas, menurut Buya Syafii Maarif, Islam membutuhkan instrumen yang disebut negara. Negara dibutuhkan guna menyokong agama. Bagi Ahmad Syafii Maarif, negara merupakan alat yang penting bagi agama. ${ }^{42}$ Namun demikian, agama (Islam) tidak harus atau dijadikan dasar negara. Aspirasi politik hendaknya bukan menjadikan Islam sebagai dasar negara dan memformalisasikan Syariat Islam, akan tetapi menjalankan kehidupan atas dasar kebersamaan dan musyawarah (syûrâ). Hal ini sejalan dengan pesan Al-Qur'ân yang menghendaki terciptanya masyarakat

\footnotetext{
39 Ahmad Syafii Maarif, Islam: Kekuatan Doktrin..., hal. 62.

40 Ahmad Syafii Maarif, Islam dan Masalah..., hal. 16.

41 Ahmad Syafii Maarif, Islam dan Masalah..., hal. 11.

42 Ibid., hal. 16.
} 
yang egaliter dengan menjalankan mekanisme syûrâ (mutual consultation). ${ }^{43}$ Menurut Buya Syafii Maarif, prinsip dasar terpokok adalah konsep syûrâ yang menjadi citacita sentral dalam cita-cita politik Al-Qur'ân. ${ }^{44}$ Prinsip syûrâ ini sesungguhnya dekat dengan sistem demokasi. Ahmad Syafii Maarif sendiri mengatakan bahwa syûrâ merupakan demokrasi khas Islam. ${ }^{45}$

Akan tetapi masalahnya, pada era sekarang ini tidaklah mudah menemukan model negara yang benar-benar menjalankan prinsip egaliter dan syûrâ di antara negara-negara yang menyebut dirinya berdasarkan Islam. Negara-negara Islam dewasa ini telah menyimpang. Selain Pakistan, Ahmad Syafii Maarif mencontohkan Iran. Negara Republik Islam yang awalnya diperkirakan dapat menjadi model negara Islam ternyata "jauh panggang daripada api". Pola kehidupan yang elitis, dengan kekuasaan para mullahnya yang mengabaikan prinsip demokrasi dalam kehidupan politik, menimbulkan kekecewaan banyak pihak. ${ }^{46}$ Ia juga menyesalkan sikap beberapa negara Muslim dan beberapa ahli hukum Islam yang sampai detik ini masih menganggap sistem politik monarkhi adalah Islam dan karenanya wajib dipertahankan. ${ }^{47}$

Dalam pandangan teo-politiknya, Buya Syafii Maarif lebih menekankan pencapaian nilai-nilai substantif Islam semisal keadilan, persamaan, kebebasan, kesejahteraan, dan seterusnya ketimbang memformalisasikan Islam menjadi dasar negara. Dengan mengutip nasehat Bung Hatta, ia mengajak umat Islam untuk lebih mengedepankan nilai-nilai substansial Islam:

"Pakailah garam, terasa tapi tidak kelihatan, dan jangan menggunakan gincu, kelihatan tapi tidak terasa. Artinya, kalau menurut filsafat garam, ajaran Islam diharapkan dapat mewarnai cara bertindak, berpikir, dan merasa, meski tidak diformalisasikan. Dampaknya pun, menurut saya, jauh lebih baik, karena akan terjadi internalisasi nilai-nilai. Yang demikian ini, lebih melihat isi daripada kulit. Karena itu, nasehat Bung Hatta patut direnungkan kembali, sehingga kita dapat membaca realitas lebih tepat lagi." ${ }^{48}$

43 Anonim, "Umat Islam Seribu Tahun Berhenti Berpikir", wawancara Prisma dengan Ahmad Syafii Maarif, Prisma No. 4, April 1984 Tahun XII, hal. 68.

44 M. Syafi'i Anwar, "Syafii Maarif, Bung Hatta, dan Deformalisasi Syariat", dalam Azyumardi Azra, dkk., Muhammadiyah dan Politik Islam Inklusif: 70 Tabun Abmad Syafii Maarif, Abd. Rohim Ghazali\&Saleh Partaonan Daulay (ed.), (Jakarta: Maarif Institute, 2005), hal. 42.

45 Ahmad Syafii Maarif, Islam dan Politik: Teori..., hal. 194.

46 Ibid.

47 Ahmad Syafii Maarif, Islam: Kekuatan Doktrin..., hal. 61.

48 Anonim, "Menawarkan Substansi Syariat Islam", Wawancara Zuhairi Misrawi dengan Ahmad Syafii Maarif, Tashwirul Afkar, Edisi No. 12 tahun 2002, hal. 107. 
Bagi Buya Syafii Maarif, negara dan atribut yang disandangnya bukanlah masalah yang fundamental dalam Islam. ${ }^{49}$ Dengan kata lain, apapun bentuk negara tidak masalah, yang penting pemerintah bisa mewujudkan kemaslahatan, kebebasan, keadilan, dan nilai-nilai substansial Islam lainnya bagi rakyat. Kekuasaan harus dibangun di atas landasan etik-moral. Ia menuturkan "kekuasaan semestinya menjadi kendaraan moral atau alat moral yang efektif untuk tegaknya moral. Jangan dibalik, di banyak negara agama atau moral yang dijadikan kendaraan untuk mencapai kekuasaan." ${ }^{50}$ Dalam landasan prinsip-prinsip moral inilah, prinsip-prinsip Islam yang lain dapat ditegakkan dengan mantap..$^{51}$

Buya Syafii Maarif mengecam para elit yang acapkali membawa nama Islam, namun prilakunya buruk dan tidak mencerminkan nilai-nilai Islam. Kendatipun pada dasarnya ia tidak keberatan dengan formalisasi Syariat Islam asal dilakukan dengan cara konstitusional dan demokratis, namun ia tetap mengkritik aspirasi tersebut. Ia menuturkan "Apa alasan kita untuk mengejar yang formal, atau lebih mengutamakan bentuknya dan melalaikan isi. Yang saya takutkan merek begitu indah, tapi isinya kosong". ${ }^{52}$ Menurutnya, suatu negara baru dapat dikatakan bercorak Islam tatkala keadilan dan prinsip-prinsip lainnya benar-benar terwujud dan mempengaruhi seluruh kehidupan rakyat. ${ }^{53}$

Pandangan Ahmad Syafii Maarif ini sama dengan pandangan Abdullah Ahmad An-Naim yang mengatakan bahwa negara Islam adalah negara yang tunduk pada prinsip-prinsip universalitas Islam seperti keadilan, kesetaraan, as-syûrâ-, kesejahteraan, dan lain-lain tanpa pelabelan nama yang dikenakannya. Kendatipun ada negara yang mengklaim diri sebagai "negara Islam", namun tidak dapat melaksanakan prinsip-prinsip tersebut, maka tidak bisa dianggap sebagai negara Islam. $^{54}$

Bagi Buya Ahmad Syafii Maarif, usaha-usaha untuk mendirikan negara Islam merupakan pekerjaan yang sia-sia. Berulangkali upaya menjadikan Islam sebagai dasar negara banyak dilakukan, berulangkali pula upaya tersebut kandas di tengah

49 Ahmad Syafii Maarif, Islam dan Politik: Teori..., hal. 193.

50 Wawancara dengan Ahmad Syafii Maarif pada 12 Januari 2009.

51 Ahmad Syafii Maarif, Islam dan Masalah..., hal. 205.

52 Wawancara dengan Ahmad Syafii Maarif pada 12 Januari 2009.

53 Ahmad Syafii Maarif, Islam dan Masalah..., hal. 16.

54 Mohammad Dahlan, "Pemikiran Abdullahi An-Naim tentang Negara Islam", Religi, Vol. III, No. 2, Juli 2004, hal. 173. 
jalan. Ketidakberhasilan kelompok Islam dalam mengelontorkan proyek negara Islam Indonesia, menurutnya, dikarenakan mereka gagal membaca peta sosiologis masyarakat Indonesia. Umat Muslim di negeri ini, kembali ia berujar, merupakan mayoritas dengan jumlah kira-kira 90 persen, akan tetapi yang menghendaki negara Islam kurang dari itu, bahkan kurang dari 50 persen. Kalangan Muslim yang sampai sekarang memperjuangkan negara Islam di mata Buya Syafii Maarif dianggap sebagai orang-orang yang ketinggalan zaman dan tidak mau belajar. Mereka tidak mau membaca literatur-literatur mutakhir tentang relasi Islam dengan negara. Kalaupun mau membaca, kata Buya Ahmad Syafii Maarif, yang dibacanya adalah literaturliteratur karya para intelektual yang mendukung gagasan negara Islam, semisal Hassan al-Banna, al-Maududi, Sayyid Qutb, dan lain-lain. ${ }^{55}$

Buya Syafii Maarif juga mengkritik kalangan yang gencar mempromosikan formalisasi Syariat Islam. Ia menuturkan bahwa kebanyakan mereka yang menghendaki pemberlakuan Syariat Islam sejatinya tidak paham tentang hakekat Syariat Islam itu sendiri. Mereka memahami Syariat Islam sebatas hukum saja, padahal Syariat sejatinya merupakan agama itu sendiri (ad-din) yang bersifat holistik. Esensinya adalah keadilan, bukan hukum-hukum yang bersifat partikular. Lebih lanjut menurut guru besar Filsafat Sejarah Universitas Negeri Yogyakarta ini, apabila Syariat dipahami sebagai potong tangan, maka akan memberi kesan bahwa Islam adalah agama yang menakutkan. ${ }^{56}$ Menurutnya, Syariat adalah agama itu sendiri yang meliputi seluruh dimensi kehidupan manusia yang berupa prinsip-prinsip moral-spiritual yang telah diturunkan sejak masa Nabi Nuh, Ibrahim, Musa, Isa, hingga sampai ke masa nabi Muhammad SAW. Adapun sistem hukum yang merupakan wilayah ijtihad hanyalah salah satu dimensi dari seluruh cakupan Syariat. ${ }^{57}$

Bagi Buya Syafii Maarif, Syariat Islam mesti dipahami sebagai nilai-nilai yang substansial. Ia menyebutnya sebagai maqâc $i d$, yang isinya tidak lain adalah tegaknya nilai-nilai fundamental Islam seperti keadilan, kesetaraan, kesejahteraan, dan lain-lain. Syariat sendiri, lebih lanjut menurutnya, merupakan hasil ijtihad yang terikat oleh zaman. Ia tidak menyangkal konsep bahwa Islam adalah $c$ alih likulli zaman wa makan, namun pemahaman manusia tentang doktrin Islam akan senantiasa mengalami

55 Wawancara dengan Ahmad Syafii Maarif pada 12 Januari 2009.

56 Anonim, "Menawarkan Substansi Syariat Islam", Wawancara Zuhairi Misrawi dengan Ahmad Syafii Maarif, Tashwirul Afkar, Edisi No. 12 tahun 2002, hal. 105-110.

57 Ahmad Syafii Maarif, Mencari Autentisitas dalam Kegalauan, (Jakarta: PSAP Muhammadiyah, 2004), hal. 72-73. 
perubahan. Hal ini karena Syariat Islam merupakan hasil ijtihad manusia yang terikat oleh ruang dan waktu. ${ }^{58}$ Karena itu, Buya Ahmad Syafii Maarif mengajak supaya umat Muslim harus senantiasa berijtihad secara terus-menerus. Hanya dengan berijtihad itulah, Islam akan mampu menjawab segenap problematika kemanusiaan. Kecenderungan umat Islam pada masa ini, menurutnya, adalah berhenti berpikir sehingga kebanyakan umat Muslim gagal membumikan ajaran Islam yang rahmatan li al-âlamîn. ${ }^{59}$

Buya Syafii Maarif mengkhawatirkan ideologisasi Islam justru akan menimbulkan perpecahan di tengah masyarakat. Perpecahan tersebut tak hanya akan melibatkan antara kelompok Muslim dan non-Muslim saja, akan tetapi juga perpecahan antarsesama umat Islam. ${ }^{60}$ Baginya, formalisasi Syariat Islam hanya akan memunculkan ketakutan terhadap Muslim abangan. "Saya yakin, akan banyak orang Islam marginal, atau kelompok masyarakat yang selama ini masuk dalam kelompok Islam pinggiran, yang justru akan lari dari Islam. Bukankah hal ini justru akan merugikan upaya dakwah Islam itu sendiri”. ${ }^{61}$

Menurut pandangannya, agama (Islam) cukup ditempatkan sebagai landasan etik dan spirit bernegara. Dalam konteks keindonesian, Buya Syafii Maarif masih meyakini bahwa Pancasila merupakan dasar negara yang tepat bagi Indonesia. Menurutnya, Pancasila sebagai dasar negara harus senantiasa disinari wahyu (agama). Di bawah sinar wahyu atau agama, Pancasila mempunyai landasan moral yang kokoh, yakni moral transendental. ${ }^{62}$ Dengan landasan moral-religius yang kokoh, bukan tidak mungkin Indonesia akan kembali menjadi pujian dunia sebagai negara yang berhasil menciptakan harmoni kehidupan beragama sebagaimana yang pernah terjadi di masa silam.

\section{Penutup}

Dari paparan di atas dapat dapat disimpulkan bahwa menurut pandangan Ahmad Syafii Maarif, secara normatif, Islam tidak menetapkan dan menegaskan

58 Wawancara dengan Ahmad Syafii Maarif pada 12 Januari 2009.

59 Wawancara dengan Ahmad Syafii Maarif pada 12 Januari 2009.

60 Wawancara Republika dengan Ahmad Syafii Maarif, "Pertimbangkan Dampak yang akan Timbul". Lihat Ahmad Syafii Maarif, dkk., Syariat Islam Yes, Syariat Islam No: Dilema Piagam Madinah dalam Amandemen UUD 1945, (Jakarta: Paramadina, 2001), hal. 41-44.

61 Ibid.

62 Ahmad Syafii Maarif, Masa Depan Bangsa dalam Taruhan, (Yogyakarta: Pustaka Suara Muhammadiyah, 2000), hal. 84-87. 
pola apapun tentang teori negara Islam yang wajib digunakan oleh kaum Muslim. Ia menolak gagasan negara Islam karena menurutnya tidak memiliki basis religiointelektual yang kukuh. Secara historis, terminologi negara Islam tidak terdapat dalam literatur Islam klasik. Ia juga menolak tesis yang mengatakan bahwa Islam merupakan dîn sekaligus daulâh.

Buya Syafii Maarif tidak mempermasalahkan adanya formalisasi Syariat Islam asal dilakukan dengan cara yang konstitusional dan demokratis. Namun demikian, ia tetap mengkritik kalangan yang menginginkan pendirian negara Islam dan formalisasi Syariat Islam di Indonesia. Selain karena alasan teologis dan historis, baginya, wacana negara Islam dan formalisasi Syariat Islam di Indonesia hanya akan membawa kemudharatan. Di matanya, kalangan yang menghendaki formalisasi Syariat Islam dianggapnya lebih menekankan bentuk daripada substansi ajaran Islam. Padahal, menurutnya perwujudan nilai-nilai substansial Islam seperti keadilan, persamaan, kesejahteraan, dan nilai-nilai substansial lainnya jauh lebih penting dibanding mengejar formalisasi. Islam harus diletakkan sebagai moralitas dalam beragama. Dengan berlandas pada prinsip-prinsip moral inilah, maka prinsip-prinsip Islam yang lain dapat ditegakkan dengan kokoh.

\section{DAFTAR PUSTAKA}

Anwar, M. Syafi'i. "Syafii Maarif, Bung Hatta, dan Deformalisasi Syariat", dalam Azyumardi Azra, dkk., Muhammadiyah dan Politik Islam Inklusif: 70 Tabun Ahmad Syafii Maarif, Abd. Rohim Ghazali\&Saleh Partaonan Daulay (ed.), Jakarta: Maarif Institute, 2005.

Azizy, A. Qodri. "Agama dalam Bernegara”, Bagian Pertama dari Dua Tulisan, Republika, Selasa 14 Agustus 2007.

Azra, Azyumardi. 2002. Konflik Baru Antar Peradaban Globalisasi, Radikalisme, dan Pluralisme, Jakarta: PT Raja Grafindo Persada.

Dahlan, Mohammad. "Pemikiran Abdullahi An-Naim tentang Negara Islam", dalam Religi Jurnal Studi Agama-Agama, Vol. III, No. 2, Juli 2004. Yogyakarta: Fakultas Ushuluddin UIN Sunan Kalijaga.

Departemen Agama. 1983. Al-Qur'ân dan Terjemahnya, Jakarta: Proyek Pengadaan Kitab Suci Al-Qur'ân.

Gatra, 6 Mei 2006. 
http $/$ www.antara.co.id $=\operatorname{arc}=2008=7=31=\mathrm{ahmad} / \mathrm{syafii} / \mathrm{maarif} / \mathrm{terima} / \mathrm{magsaysav} /$ award htm/accessed 3 Januari 2009.

Husaini, Adian. "Syariat Islam di Indonesia: Problem Masyarakat Muslim Kontemporer", Tashwirul Afkar, Edisi No. 12 Tahun 2002. Jakarta: LAKPESDAMNU.

Ichwan, Moch. Nur. "Ulama and Politics", dalam Noorhaidi Hasan, dkk. 2007. Moving with the Times: the Dynamics of Contemporary Islam in a Changing Indonesia, Moch. Nur Ichwan \& Noorhaidi Hasan (eds.), Yogyakarta: CISform UIN Sunan Kalijaga.

Jahroni, Jajang. "Khilafah Islam: Khilafah yang Mana?” dalam Abd. Moqsith Ghazali, dkk. 2005. Ijtihad Islam Liberal: Upaya Merumuskan Keberagamaan yang Dinamis, Jakarta: Jaringan Islam Liberal.

Kamseno, Sigit. "Komprehensivisme Dîn al-Islâm: Kritik atas Konsep Kulturalisme dan Strukturalisme Islam”, dalam Jurnal Politik Islam, Vol. 1, No. 2, 2006/ 1427. Jakarta: Laboratorium Politik Islam, Fakultas Ushuluddin dan Filsafat UIN Syarif Hidayatullah.

Ma'arif, Zaenul. "Menggali Akar Fundamentalisme Islam: Paradigma Sebagai Pisau Analisis", dikutip dari http://islamlib.com/id/index.php?page $=$ article\&id $=74$ Laccessed 18 Desember 2006.

Maarif, Ahmad Syafii. 1985. Islam dan Masalah Kenegaraan: Studi tentang Percaturan dalam Konstituante, Jakarta: LP3ES.

, "Islam di Masa Demokrasi Liberal dan Demokrasi Terpimpin", dalam Prisma No. 5, Tahun XVIII, 1988.

, 1988. Islam dan Politik di Indonesia Pada Masa Demokrasi Terpimpin (1959-1965), Yogyakarta: IAIN Sunan Kalijaga Press.

, 1996. Islam dan Politik: Teori Belah Bambu Masa Demokrasi Terpimpin (1959-1965), Jakarta: Gema Insani Press.

, 1997. Islam Kekuatan Doktrin dan Kegamangan Umat, Yogyakarta: Pustaka Pelajar.

-, 2000. Masa Depan Bangsa dalam Taruhan, Yogyakarta: Pustaka Suara Muhammadiyah. 
, 2004. Mencari Autentisitas dalam Kegalauan, Jakarta: PSAP Muhammadiyah. -, 2006. Titik-Titik Kisar Di Perjalananku: Otobiografi Abmad Syafii Maarif, Yogyakarta: Penerbit Ombak-Maarif Institute.

Maarif, Ahmad Syafii, dkk. 2001. Syariat Islam Yes, Syariat Islam No: Dilema Piagam Madinah dalam Amandemen UUD 1945, Jakarta: Paramadina.

Misrawi, Zuhairi, “Dekonstruksi Syariat: Jalan Menuju Desakralisasi, Reinterpretasi, dan Depolitisasi", Tashwirul Afkar, Edisi No. 12 Tahun 2002. Jakarta: LAKPESDAMNU.

Nashir, Haedar. 2007. Gerakan Islam Syariat: Reproduksi Salafiyab Ideologis di Indonesia, Rizaluddin Kurniawan (ed.), Jakarta: PSAP Muhammadiyah.

Qardawi, Yusuf al-. 1987. Figh Negara, alih bahasa Syafri Hakim, Jakarta: Robbi Press.

Rakhmat, Jalaluddin. 1986. Islam Alternatif, Bandung: Mizan.

Salim, Arskal, dkk. 2003. Syariat Islam: Pandangan Muslim Liberal, Burhanuddin (ed.), Jakarta: Jaringan Islam Liberal-The Asia Foundation.

Selly, Rosi, "Kebangkitan Khilafah Islamiyah di Tengah Arus Global”, dalam Jurnal Politik Islam, volume I, nomor 2, 2006/1427. Jakarta: Laboratorium Politik Islam, Fakultas Ushuluddin dan Filsafat UIN Syarif Hidayatullah.

Sjadzali, Munawwir. 1990. Islam dan Tata Negara: Ajaran, Sejarah, dan Pemikiran, Jakarta: UI Press.

Wahid, Abdurrahman. 2006. Islamku Islam Anda Islam Kita: Agama Masyarakat Negara Demokrasi, Jakarta: The Wahid Institute.

Wawancara dengan Ahmad Syafii Maarif pada 12 Januari 2009. 